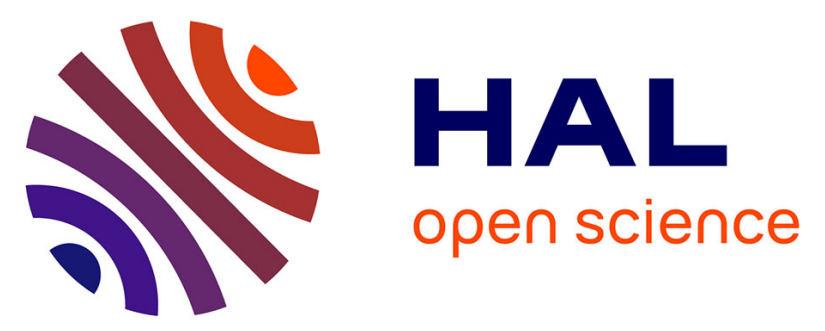

\title{
Interaction of a selective serotonin reuptake inhibitor with insulin in the control of hepatic glucose uptake in conscious dogs
}

Mary Courtney Moore, Catherine A. Di Costanzo, Dominique Dardevet, Margaret Lautz, Ben Farmer, Alan D. Cherrington

\section{To cite this version:}

Mary Courtney Moore, Catherine A. Di Costanzo, Dominique Dardevet, Margaret Lautz, Ben Farmer, et al.. Interaction of a selective serotonin reuptake inhibitor with insulin in the control of hepatic glucose uptake in conscious dogs. AJP - Endocrinology and Metabolism, 2005, 288 (3), pp.E556E563. 10.1152/ajpendo.00405.2004 . hal-02679344

\section{HAL Id: hal-02679344 \\ https://hal.inrae.fr/hal-02679344}

Submitted on 31 May 2020

HAL is a multi-disciplinary open access archive for the deposit and dissemination of scientific research documents, whether they are published or not. The documents may come from teaching and research institutions in France or abroad, or from public or private research centers.
L'archive ouverte pluridisciplinaire HAL, est destinée au dépôt et à la diffusion de documents scientifiques de niveau recherche, publiés ou non, émanant des établissements d'enseignement et de recherche français ou étrangers, des laboratoires publics ou privés. 
Mary Courtney Moore, Catherine A. DiCostanzo, Dominique Dardevet, Margaret Lautz, Ben Farmer and Alan D. Cherrington

Am J Physiol Endocrinol Metab 288:556-563, 2005. First published Nov 2, 2004;

doi:10.1152/ajpendo.00405.2004

You might find this additional information useful...

This article cites 40 articles, 21 of which you can access free at:

http://ajpendo.physiology.org/cgi/content/full/288/3/E556\#BIBL

Updated information and services including high-resolution figures, can be found at:

http://ajpendo.physiology.org/cgi/content/full/288/3/E556

Additional material and information about AJP - Endocrinology and Metabolism can be found at:

http://www.the-aps.org/publications/ajpendo

This information is current as of September 3, 2010 .

AJP - Endocrinology and Metabolism publishes results of original studies about endocrine and metabolic systems on any level of organization. It is published 12 times a year (monthly) by the American Physiological Society, 9650 Rockville Pike, Bethesda MD 20814-3991. Copyright @ 2005 by the American Physiological Society. ISSN: 0193-1849, ESSN: 1522-1555. Visit our website at http://www.the-aps.org/. 


\title{
Interaction of a selective serotonin reuptake inhibitor with insulin in the control of hepatic glucose uptake in conscious dogs
}

\author{
Mary Courtney Moore, ${ }^{1,2}$ Catherine A. DiCostanzo, ${ }^{1}$ Dominique Dardevet, ${ }^{1}$ \\ Margaret Lautz, ${ }^{\mathbf{1}}$ Ben Farmer, ${ }^{\mathbf{1}}$ and Alan D. Cherrington ${ }^{\mathbf{1}, 2}$ \\ ${ }^{1}$ Department of Molecular Physiology and Biophysics and ${ }^{2}$ Diabetes Research \\ and Training Center, Vanderbilt University School of Medicine, Nashville, Tennessee
}

Submitted 27 August 2004; accepted in final form 29 October 2004

\begin{abstract}
Moore, Mary Courtney, Catherine A. DiCostanzo, Dominique Dardevet, Margaret Lautz, Ben Farmer, and Alan D. Cherrington. Interaction of a selective serotonin reuptake inhibitor with insulin in the control of hepatic glucose uptake in conscious dogs. Am J Physiol Endocrinol Metab 288: E556-E563, 2005. First published November 2, 2004; doi:10.1152/ajpendo.00405.2004.Whether hyperinsulinemia is required for stimulation of net hepatic glucose uptake (NHGU) by a selective serotonin reuptake inhibitor (SSRI) was examined in four groups of conscious 42-h-fasted dogs, using arteriovenous difference and tracer $\left(\left[3-{ }^{3} \mathrm{H}\right]\right.$ glucose $)$ techniques. Experiments consisted of equilibration $(-120$ to $-30 \mathrm{~min})$, basal ( -30 to $0 \mathrm{~min}$ ), and experimental periods (Exp; 0-240 min). During Exp, somatostatin, intraportal insulin [at basal (Ins groups) or 4-fold basal rates (INS groups)], basal intraportal glucagon, and peripheral glucose (to double hepatic glucose load) were infused. In the Fluv-Ins $(n=7)$ and Fluv-INS groups $(n=6)$, saline was infused intraportally from 0 to $90 \mathrm{~min}(P 1)$, and fluvoxamine was infused intraportally at $2 \mu \mathrm{g} \cdot \mathrm{kg}^{-1} \cdot \min ^{-1}$ from 90 to $240 \mathrm{~min}(P 2)$. Sal-Ins $(n=9)$ and Sal-INS $(n=8)$ received intraportal saline in $P 1$ and $P 2$. NHGU during $P 2$ was $8.4 \pm 1.4$ and $6.9 \pm 2.3 \mu \mathrm{mol} \cdot \mathrm{kg}^{-1} \cdot \mathrm{min}^{-1}$ in Sal-Ins and Fluv-Ins, respectively (not significant), and $13.3 \pm 2.2$ and $20.9 \pm$ $3.1 \mu \mathrm{mol} \cdot \mathrm{kg}^{-1} \cdot \min ^{-1}(P<0.05)$ in Sal-INS and Fluv-INS. Unidirectional (tracer-determined) hepatic glucose uptake was twofold greater $(P<0.05)$ in Fluv-INS than Sal-INS. Net hepatic carbon retention during $P 2$ was significantly greater in Fluv-INS than SalINS $\left(18.5 \pm 2.7\right.$ vs. $\left.12.2 \pm 1.9 \mu \mathrm{mol} \cdot \mathrm{kg}^{-1} \cdot \mathrm{min}^{-1}\right)$. Nonhepatic glucose uptake was reduced in Fluv-INS vs. Sal-INS $(20.0 \pm 1.3$ vs. $\left.38.4 \pm 5.4 \mu \mathrm{mol} \cdot \mathrm{kg}^{-1} \cdot \mathrm{min}^{-1}, P<0.05\right)$. Intraportal fluvoxamine enhanced NHGU and net hepatic carbon retention in the presence of hyperinsulinemia but not euinsulinemia, suggesting that hepatocytetargeted SSRIs may reduce postprandial hyperglycemia.
\end{abstract}

glycemia; liver; fluvoxamine

INTRAPORTAL INFUSION OF SEROTONIN (5-hydroxytryptamine; 5-HT) (22) and the selective serotonin reuptake inhibitor (SSRI) fluvoxamine (20) enhanced net hepatic glucose uptake (NHGU) in conscious dogs during a hyperinsulinemic hyperglycemic clamp. Although the exact mechanism for this action is unclear, it suggests that SSRIs or 5-HT agonists might provide a tool for reducing postprandial glycemia in individuals with diabetes. This raises the question of whether SSRI treatment would be effective in the presence of a relative deficiency of insulin. Therefore, we examined NHGU and total body glucose disposal $\left(\mathrm{R}_{\mathrm{d}}\right)$ in conscious dogs during intraportal infusion of fluvoxamine under conditions of hyperglycemia and either euinsulinemia or hyperinsulinemia. Fluvoxamine

Address for reprint requests and other correspondence: M. C. Moore, 702 Light Hall, Dept of Molecular Physiology \& Biophysics, Vanderbilt Univ School of Medicine, Nashville, TN 37232-0615 (E-mail: genie.moore@ vanderbilt.edu). was effective in bringing about a significant enhancement of NHGU and hepatic carbon storage in the presence of hyperinsulinemia but not euinsulinemia.

\section{RESEARCH DESIGN AND METHODS}

Animals and surgical procedures. Studies were carried out on conscious 42-h-fasted mongrel dogs of either sex with a mean weight of $22.8 \pm 0.4 \mathrm{~kg}$. Diet and housing were as previously described (29), and the protocol was approved by the Vanderbilt University Institutional Animal Care and Use Committee. The 42-h fast is well tolerated by the dog, which exhibits little change in blood glucose $(\Delta 0.2-0.3$ $\mathrm{mM}$ ) and only a $10 \%$ increase in plasma glucagon between 18 and $42 \mathrm{~h}$ of fasting (24). However, it reduces the hepatic glycogen to a stable concentration, which decreases the variability of NHGU in response to hyperglycemia and hyperinsulinemia. The dog, as well as the human, exhibits marked variability in hepatic glycogen content during a fast shorter than $40 \mathrm{~h}(8,32)$.

Approximately 16 days before study, each dog underwent a laparotomy for placement of ultrasonic flow probes (Transonic Systems, Ithaca, NY) around the portal vein and the hepatic artery, as well as for insertion of silicone rubber catheters for sampling in a hepatic vein, the portal vein, and a femoral artery and for infusion into a splenic and a jejunal vein, as described in detail elsewhere $(25,29)$. Criteria for inclusion in the study were as previously described $(25,29)$.

On the morning of the study, catheters and flow probe leads were exteriorized from their subcutaneous pockets $(25,29)$. The splenic and jejunal catheters were used for intraportal infusion of insulin (Eli Lilly, Indianapolis, IN), glucagon (GlucaGen; Bedford Laboratories, Bedford, $\mathrm{OH}$ ), and fluvoxamine maleate (Tocris, Ellisville, MO). Angiocaths (Deseret Medical, Sandy, UT) were inserted into three peripheral veins.

Experimental design. Each experiment consisted of a 90-min equilibration period ( -120 to $-30 \mathrm{~min})$, a 30 -min basal period $(-30$ to 0 $\mathrm{min}$ ), and a 240-min experimental period (0 to $240 \mathrm{~min}$ ) divided into two subperiods ( $P 1,0-90 \mathrm{~min} ; P 2,90-240 \mathrm{~min}$; Fig. 1). At -120 min, a primed continuous infusion of $\left[3-{ }^{3} \mathrm{H}\right]$ glucose and a continuous infusion of indocyanine green (ICG) dye were begun in all dogs (22). At $0 \mathrm{~min}$, a constant peripheral infusion of somatostatin (0.8 $\mu \mathrm{g} \cdot \mathrm{kg}^{-1} \cdot \min ^{-1}$; Bachem, Torrance, CA) was begun to suppress endogenous insulin and glucagon secretion. Insulin was infused intraportally at either basal $\left(0.3 \mathrm{mU} \cdot \mathrm{kg}^{-1} \cdot \mathrm{min}^{-1}\right.$; Ins groups $)$ or fourfold basal rates $\left(1.2 \mathrm{mU} \cdot \mathrm{kg}^{-1} \cdot \mathrm{min}^{-1}\right.$; INS groups), and glucagon $\left(0.55 \mathrm{ng} \cdot \mathrm{kg}^{-1} \cdot \mathrm{min}^{-1}\right)$ was replaced intraportally in basal amounts. In addition, a primed continuous variable-rate infusion of $50 \%$ dextrose was begun through a peripheral vein to maintain the hepatic glucose load at twofold basal. During $P 1$, all dogs received an intraportal saline infusion. At the end of $P 1$, the Ins and INS groups were each divided into two groups. In Sal-Ins $(n=9)$ and Sal-INS $(n=8)$, the intraportal saline infusion continued for the remainder of the study. In

The costs of publication of this article were defrayed in part by the payment of page charges. The article must therefore be hereby marked "advertisement" in accordance with 18 U.S.C. Section 1734 solely to indicate this fact. 


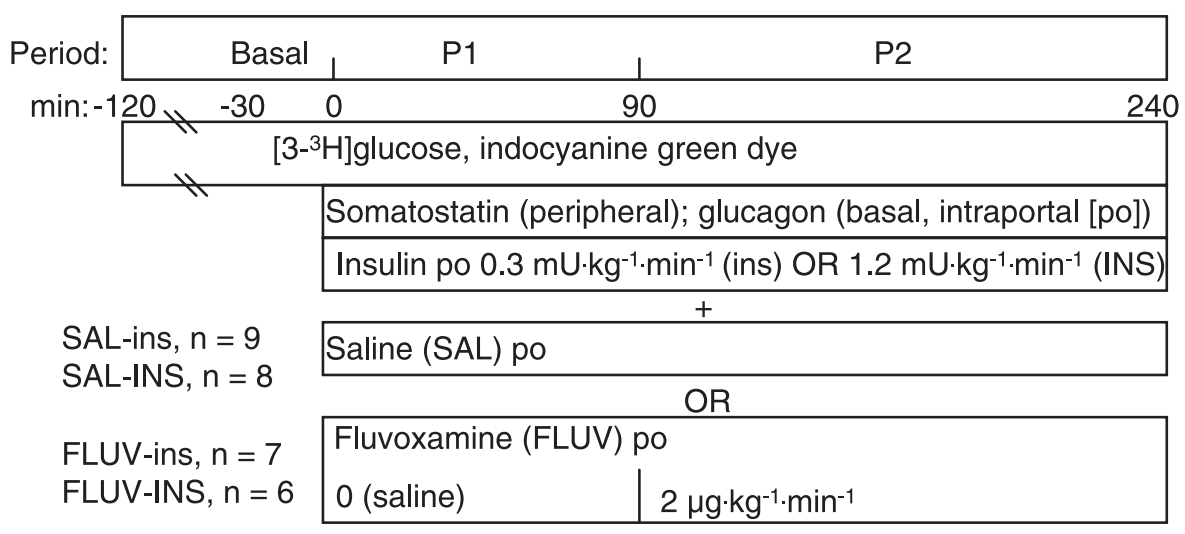

Fig. 1. Protocol design. For details, see ReSEArCH DESIGN AND METHODS.
Fluv-Ins $(n=7)$ and Fluv-INS $(n=6)$, fluvoxamine was infused into the portal vein at $2 \mu \mathrm{g} \cdot \mathrm{kg}^{-1} \cdot \min ^{-1}$ (a rate that we had previously demonstrated to enhance NHGU under hyperinsulinemic hyperglycemic conditions; Ref. 20) during $P 2$. The intraportal infusion allowed us to target the liver specifically with fluvoxamine. Fluvoxamine was chosen because of its selectivity for the serotonin receptor over other monoamine receptors $(35)$ and its extensive $(\sim 45 \%)$ first-pass extraction by the liver (37), which reduced the potential for circulating fluvoxamine to impact nonhepatic glucose uptake (non-HGU). In addition, the dosage was kept low (a total of $0.3 \mathrm{mg} / \mathrm{kg}$, compared with a usual daily therapeutic dose of $2-4 \mathrm{mg} / \mathrm{kg}$ ) to reduce the potential for systemic effects of fluvoxamine.

Femoral artery, portal vein, and hepatic vein blood samples were taken every 15-30 min throughout the study as previously described $(25,29)$. Arterial blood samples were also taken every $5 \mathrm{~min}$ throughout the experimental period to monitor the glucose level $(25,29)$. After completion of each experiment, the animal was anesthetized, biopsies were rapidly taken from three liver lobes and freeze-clamped with tongs chilled in liquid nitrogen, and the dog was euthanized with an overdose of pentobarbital sodium.

Processing and analysis of samples. Hematocrit; blood glucose, lactate, and glycerol; and plasma glucose, nonesterified fatty acids (NEFA), insulin, glucagon, cortisol, catecholamines, and $\left[{ }^{3} \mathrm{H}\right]$ glucose were measured as described previously $(25,29,33)$. 5-HT concentrations were determined on whole blood by an HPLC-amperometric assay (30) with a coefficient of variance (CV) of $4 \%$, as previously described (22). Hepatic glycogen concentrations were determined by the method of Keppler and Decker (14).

Calculations and data analysis. Hepatic blood flow was measured with ultrasonic flow probes and by use of ICG extraction. The two methods yielded similar results, but the data reported here were calculated with the ultrasonic-determined flows, because their measurement did not require an assumption regarding the relative contribution of arterial and portal flow to total hepatic blood flow.

The rate of glucose delivery to the liver, or hepatic glucose load; net hepatic substrate balance (NHB); net hepatic fractional substrate extraction; net hepatic carbon retention; hepatic sinusoidal insulin and glucagon concentrations; non-HGU; and glucose turnover were calculated as described previously (27). NHB was calculated for both cold (nonradioactive) and $\left[3-{ }^{3} \mathrm{H}\right]$ glucose, with the values for $\left[3-{ }^{3} \mathrm{H}\right]$ glucose being divided by the inflowing (weighted for the proportion of hepatic flow provided by the hepatic artery and portal vein) tritiated glucose specific activity to yield unidirectional hepatic glucose uptake (33). During the first hour of glucose infusion, the non-HGU was corrected for the glucose required to fill the pool, using a pool fraction of $0.65(5)$ and assuming that the volume of distribution for glucose equaled the volume of the extracellular fluid, or $\sim 22 \%$ of the dog's weight (34). For all glucose balance calculations, glucose concentrations were converted from plasma to blood values by using correction factors (ratio of the blood to the plasma concentration) as previously established in our laboratory $(11,12,29)$.
Net hepatic glycogen synthesis was determined by subtracting the glycogen concentrations of 11 42-h-fasted dogs that did not undergo study (19) from the final hepatic glycogen concentrations in the dogs studied.

Statistical analysis. All data are presented as means \pm SE. Time course data were analyzed with repeated-measures analysis of variance, with post hoc comparisons by Tukey's test (SigmaStat; Jandel Scientific, Chicago, IL). Statistical significance was accepted at $P<$ 0.05 . Values for $P 1$ are means of the last $30 \mathrm{~min}(60-90 \mathrm{~min})$ when steady-state conditions prevailed. Values for $P 2$ are means of all samples between 120 and $240 \mathrm{~min}$.

\section{RESULTS}

5-HT and hormone concentrations. Arterial and portal blood 5-HT concentrations remained no different from basal values in all groups throughout the experimental periods (Table 1).

The arterial and hepatic sinusoidal plasma insulin concentrations (Table 1) remained at basal levels in the Ins groups and were approximately fourfold greater in the INS groups during $P 1-P 2$. There were no differences in the insulin concentrations in the Sal-Ins and Fluv-Ins groups or between the Sal-INS and Fluv-INS groups. Arterial and hepatic sinusoidal plasma glucagon concentrations were basal and indistinguishable in all groups throughout the experiments (Table 1). The cortisol and catecholamine concentrations remained basal in all groups throughout the experiments (data not shown).

Hepatic blood flow, blood glucose concentrations, and hepatic glucose load. Portal vein blood flow decreased significantly in all groups during $P l$ as a response to somatostatin infusion and did not change significantly thereafter (Table 2). There was a concomitant increase in hepatic artery flow such that total flow fell by $\approx 10 \%$. There were no significant differences in hepatic artery or portal vein blood flow between Sal-Ins and Fluv-Ins or between Sal-INS and Fluv-INS.

Arterial blood glucose levels in all groups increased from basal values of $4.5 \pm 0.1$ to $\sim 9.3 \pm 0.2 \mathrm{mmol} / 1$ during $P 1$ and $P 2$ (Fig. 2). The hepatic glucose loads increased from a basal rate of $\sim 140$ to $270 \mu \mathrm{mol} \cdot \mathrm{kg}^{-1} \cdot \mathrm{min}^{-1}$ during $P 1$ and $P 2$ and were not significantly different among the four groups at any time (Fig. 2).

Net hepatic glucose balance and net hepatic fractional glucose extraction. The groups exhibited similar rates of net hepatic glucose output during the basal period. Coincident with the start of the experimental period, they switched from net production to net uptake, with no significant difference in the rates between the Sal-Ins and Fluv-Ins groups, respectively, during $P 1\left(6.3 \pm 1.7\right.$ and $\left.2.4 \pm 2.5 \mu \mathrm{mol} \cdot \mathrm{kg}^{-1} \cdot \mathrm{min}^{-1}\right)$ or $P 2$ 
Table 1. Serotonin and hormone concentrations

\begin{tabular}{|c|c|c|c|c|c|}
\hline \multirow{2}{*}{$\begin{array}{l}\text { Parameter } \\
\text { and Group }\end{array}$} & \multirow[b]{2}{*}{ Basal Period } & \multirow{2}{*}{$\frac{P 1}{90 \mathrm{~min}}$} & \multicolumn{3}{|c|}{$P 2$} \\
\hline & & & $120 \min$ & $180 \min$ & $240 \mathrm{~min}$ \\
\hline \multicolumn{6}{|c|}{ Arterial blood 5-HT, $\mu \mathrm{g} / \mathrm{l}$} \\
\hline Sal-Ins & $1,033 \pm 321$ & $1,069 \pm 252$ & $1,270 \pm 350$ & $1,109 \pm 263$ & $937 \pm 245$ \\
\hline Fluv-Ins & $1,623 \pm 341$ & $1,648 \pm 411$ & $1,676 \pm 439$ & $1,725 \pm 425$ & $1,635 \pm 418$ \\
\hline Sal-INS & $716 \pm 177$ & $707 \pm 110$ & $831 \pm 84$ & $642 \pm 165$ & $539 \pm 132$ \\
\hline Fluv-INS & $682 \pm 292$ & $683 \pm 295$ & $691 \pm 295$ & $588 \pm 255$ & $586 \pm 254$ \\
\hline \multicolumn{6}{|c|}{ Portal blood 5-HT, $\mu g / l$} \\
\hline Sal-Ins & $1,106 \pm 272$ & $1,218 \pm 226$ & $1,203 \pm 374$ & $1,066 \pm 216$ & $1,027 \pm 225$ \\
\hline Fluv-Ins & $1,641 \pm 332$ & $1,722 \pm 327$ & $1,683 \pm 356$ & $1,528 \pm 321$ & $1,508 \pm 328$ \\
\hline Sal-INS & $770 \pm 212$ & $778 \pm 171$ & $847 \pm 94$ & $801 \pm 102$ & $665 \pm 132$ \\
\hline Fluv-INS & $638 \pm 270$ & $672 \pm 282$ & $628 \pm 257$ & $558 \pm 223$ & $535 \pm 212$ \\
\hline \multicolumn{6}{|c|}{ Arterial plasma insulin, pmol/l } \\
\hline Sal-Ins & $37 \pm 6$ & $26 \pm 3$ & $26 \pm 3$ & $27 \pm 3$ & $29 \pm 4$ \\
\hline Fluv-Ins & $40 \pm 5$ & $26 \pm 2$ & $25 \pm 3$ & $27 \pm 4$ & $26 \pm 2$ \\
\hline Sal-INS & $51 \pm 7$ & $141 \pm 14$ & $131 \pm 11$ & $149 \pm 10$ & $156 \pm 18$ \\
\hline Fluv-INS & $52 \pm 10$ & $116 \pm 16$ & $127 \pm 19$ & $134 \pm 13$ & $124 \pm 21$ \\
\hline \multicolumn{6}{|c|}{ Hepatic sinusoidal insulin, pmol/l } \\
\hline Sal-Ins & $94 \pm 12$ & $109 \pm 16$ & $92 \pm 16$ & $93 \pm 7$ & $84 \pm 9$ \\
\hline Fluv-Ins & $90 \pm 15$ & $111 \pm 15$ & $101 \pm 13$ & $103 \pm 9$ & $87 \pm 11$ \\
\hline Sal-INS & $146 \pm 24$ & $462 \pm 47$ & $556 \pm 73$ & $478 \pm 49$ & $515 \pm 39$ \\
\hline Fluv-INS & $162 \pm 32$ & $504 \pm 92$ & $606 \pm 122$ & $517 \pm 64$ & $513 \pm 89$ \\
\hline \multicolumn{6}{|c|}{ Arterial plasma glucagon, $n g / l$} \\
\hline Sal-Ins & $39 \pm 4$ & $38 \pm 2$ & $40 \pm 4$ & $35 \pm 3$ & $34 \pm 3$ \\
\hline Fluv-Ins & $39 \pm 4$ & $37 \pm 4$ & $31 \pm 4$ & $31 \pm 3$ & $31 \pm 4$ \\
\hline Sal-INS & $46 \pm 6$ & $43 \pm 7$ & $40 \pm 6$ & $38 \pm 4$ & $35 \pm 6$ \\
\hline Fluv-INS & $37 \pm 4$ & $35 \pm 5$ & $35 \pm 4$ & $42 \pm 6$ & $31 \pm 5$ \\
\hline \multicolumn{6}{|c|}{ Hepatic sinusoidal glucagon, $n g / l$} \\
\hline Sal-Ins & $45 \pm 6$ & $52 \pm 3$ & $50 \pm 6$ & $46 \pm 3$ & $37 \pm 7$ \\
\hline Fluv-Ins & $45 \pm 6$ & $40 \pm 4$ & $38 \pm 5$ & $37 \pm 6$ & $42 \pm 9$ \\
\hline Sal-INS & $46 \pm 5$ & $54 \pm 7$ & $54 \pm 7$ & $52 \pm 6$ & $45 \pm 6$ \\
\hline Fluv-INS & $42 \pm 4$ & $50 \pm 10$ & $50 \pm 13$ & $50 \pm 9$ & $51 \pm 10$ \\
\hline
\end{tabular}

Values are means \pm SE. INS, dogs received 4-fold basal intraportal insulin during period $1(P 1)$ to period 2 ( $P 2)$; Ins, dogs received basal intraportal insulin; Sal, dogs received intraportal saline infusion during $P 1-P 2$; Fluv, dogs received intraportal saline during $P 1$ and fluvoxamine at $2.0 \mu \mathrm{g} \cdot \mathrm{kg}^{-1} \cdot \mathrm{min}^{-1} \mathrm{during} P 2$; 5-HT, 5-hydroxytryptamine. There were no significant differences between the Sal-Ins $(n=9)$ and Fluv-Ins $(n=7)$ groups or between the SAL-INS $(n=8)$ and Fluv-INS $(n=6)$ groups.

Table 2. Hepatic blood flow and glucose $R_{d}$

\begin{tabular}{|c|c|c|c|c|c|}
\hline \multirow{2}{*}{$\begin{array}{l}\text { Parameter } \\
\text { and Group }\end{array}$} & \multirow{2}{*}{$\begin{array}{l}\text { Basal } \\
\text { Period }\end{array}$} & \multirow{2}{*}{$\frac{P 1}{90 \mathrm{~min}}$} & \multicolumn{3}{|c|}{$P 2$} \\
\hline & & & $120 \mathrm{~min}$ & $180 \mathrm{~min}$ & $240 \min$ \\
\hline \multicolumn{6}{|c|}{ Hepatic artery flow, $\mathrm{ml} \cdot \mathrm{kg}^{-1} \cdot \mathrm{min}^{-1}$} \\
\hline Sal-Ins & $5.9 \pm 0.7$ & $6.5 \pm 1.1$ & $6.6 \pm 1.0$ & $6.5 \pm 1.0$ & $7.6 \pm 1.6$ \\
\hline Fluv-Ins & $6.1 \pm 0.9$ & $6.6 \pm 1.7$ & $7.2 \pm 1.7$ & $7.1 \pm 1.9$ & $7.1 \pm 1.8$ \\
\hline Sal-INS & $6.3 \pm 1.0$ & $7.3 \pm 1.0$ & $7.3 \pm 0.9$ & $8.1 \pm 1.1$ & $8.4 \pm 1.2$ \\
\hline Fluv-INS & $4.8 \pm 0.7$ & $6.1 \pm 1.0$ & $5.3 \pm 0.9$ & $6.1 \pm 0.8$ & $6.3 \pm 0.8$ \\
\hline \multicolumn{6}{|c|}{ Portal vein flow, $\mathrm{ml} \cdot \mathrm{kg}^{-1} \cdot \mathrm{min}^{-1}$} \\
\hline Sal-Ins & $28.5 \pm 2.2$ & $22.7 \pm 1.4$ & $22.9 \pm 1.3$ & $22.7 \pm 1.1$ & $22.3 \pm 1.5$ \\
\hline Fluv-Ins & $30.1 \pm 2.5$ & $25.6 \pm 2.8$ & $23.8 \pm 1.4$ & $26.3 \pm 2.9$ & $24.2 \pm 1.4$ \\
\hline Sal-INS & $25.2 \pm 2.4$ & $21.1 \pm 2.0$ & $22.1 \pm 1.6$ & $20.3 \pm 2.0$ & $20.4 \pm 2.1$ \\
\hline Fluv-INS & $25.7 \pm 3.4$ & $19.9 \pm 2.5$ & $20.3 \pm 3.4$ & $22.4 \pm 2.9$ & $24.2 \pm 3.3$ \\
\hline \multicolumn{6}{|c|}{ Glucose $R_{d}, \mu \mathrm{mol} \cdot \mathrm{kg}^{-1} \cdot \mathrm{min}^{-1}$} \\
\hline Sal-Ins & $13.8 \pm 0.8$ & $24.9 \pm 3.0$ & $25.5 \pm 3.4$ & $24.8 \pm 3.2$ & $27.1 \pm 3.4$ \\
\hline Fluv-Ins & $14.9 \pm 0.8$ & $24.4 \pm 2.2$ & $24.8 \pm 2.7$ & $24.8 \pm 3.2$ & $25.6 \pm 4.3$ \\
\hline Sal-INS & $12.9 \pm 0.5$ & $45.8 \pm 4.1$ & $51.2 \pm 5.2$ & $58.1 \pm 6.5$ & $69.6 \pm 9.9$ \\
\hline Fluv-INS & $12.5 \pm 0.6$ & $39.5 \pm 5.7$ & $42.9 \pm 6.1$ & $48.4 \pm 6.0$ & $58.8 \pm 10.5$ \\
\hline
\end{tabular}

Values are means \pm SE. For group descriptions, see legend to Table 1. $R_{d}$, rate of disappearance. There were no significant differences between the Sal-Ins $(n=9)$ and Fluv-Ins $(n=7)$ groups or between the Sal-INS $(n=8)$ and Fluv-INS $(n=6)$ groups. 

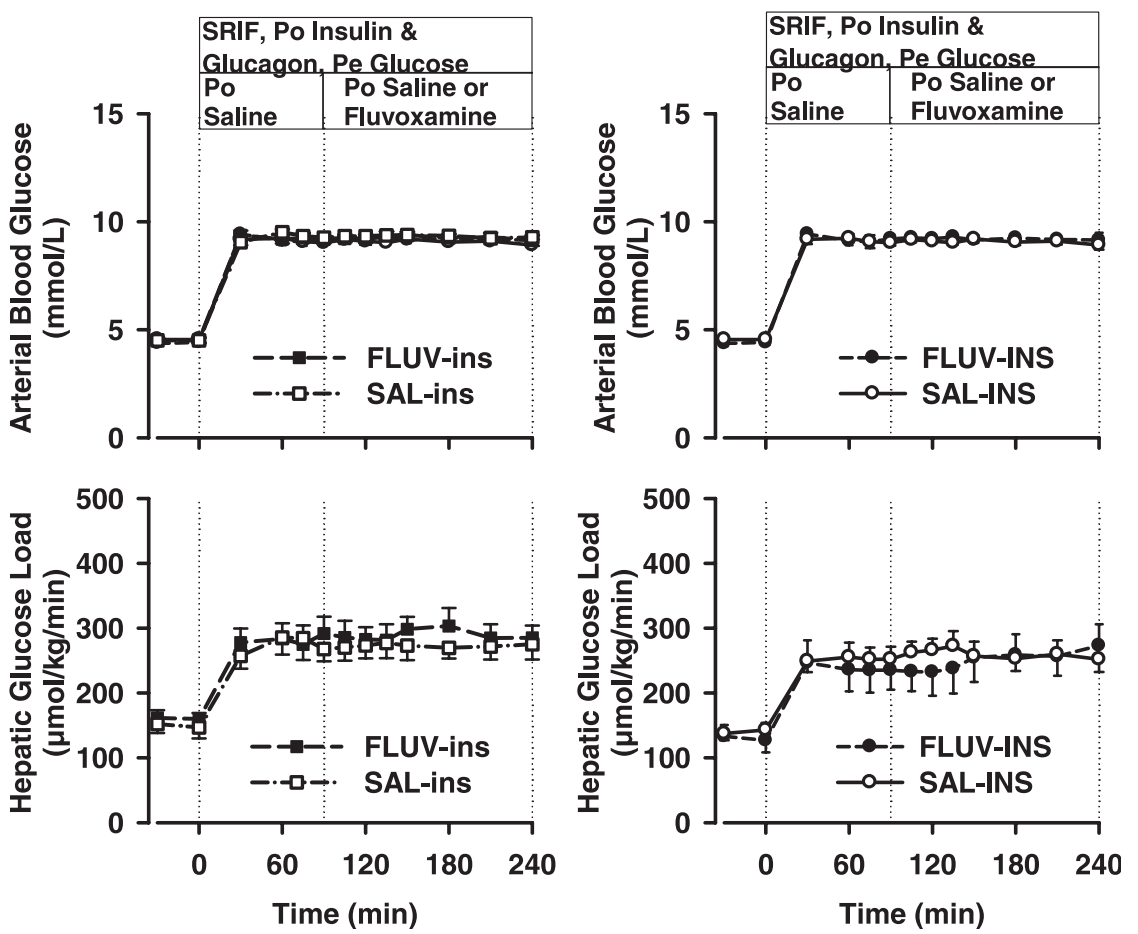

$\left(8.4 \pm 1.4\right.$ and $6.9 \pm 2.3 \mu \mathrm{mol} \cdot \mathrm{kg}^{-1} \cdot \mathrm{min}^{-1}$; Fig. 3). Unidirectional hepatic glucose uptake (tracer determined) did not differ at any time between groups (data not shown). Net hepatic fractional extraction of glucose was similarly unaffected by fluvoxamine $(0.029 \pm 0.006$ and $0.026 \pm 0.010$ during $P 2$ in the Sal-Ins and Fluv-Ins groups, respectively).

NHGU in the Sal-INS and Fluv-INS groups, respectively, averaged $10.7 \pm 2.2$ and $12.7 \pm 2.3 \mu \mathrm{mol} \cdot \mathrm{kg}^{-1} \cdot \mathrm{min}^{-1}$ during P1 [not significant (NS); Fig. 3]. Subsequently the rate of NHGU remained relatively stable in Sal-INS $(13.3 \pm 2.3$ $\mu \mathrm{mol} \cdot \mathrm{kg}^{-1} \cdot \min ^{-1}$ during $\left.P 2\right)$ but increased significantly in Fluv-INS $\left(20.9 \pm 3.1 \mu \mathrm{mol} \cdot \mathrm{kg}^{-1} \cdot \mathrm{min}^{-1}, P<0.05\right.$ between groups). Unidirectional hepatic glucose uptake was also enhanced by fluvoxamine infusion during $P 2$ (14.2 \pm 3.7 vs. $24.6 \pm 2.8 \mu \mathrm{mol} \cdot \mathrm{kg}^{-1} \cdot \mathrm{min}^{-1}$ in Sal-INS and Fluv-INS, respectively; $P<0.05)$. Additionally, net hepatic fractional extraction of glucose during $P 2$ was greater in Fluv-INS than in Sal-INS, averaging $0.085 \pm 0.009$ vs. $0.056 \pm 0.009(P<$ $0.05)$.
Glucose infusion rates, non-HGU, glucose rate of appearance, and glucose $R_{d}$. The glucose infusion rates (GIRs) in Sal-Ins and Fluv-Ins did not differ significantly during either $P 1$ (19.6 \pm 3.6 vs. $\left.15.9 \pm 4.0 \mu \mathrm{mol} \cdot \mathrm{kg}^{-1} \cdot \mathrm{min}^{-1}\right)$ or $P 2$ $\left(21.4 \pm 2.9\right.$ vs. $\left.18.4 \pm 3.3 \mu \mathrm{mol} \cdot \mathrm{kg}^{-1} \cdot \mathrm{min}^{-1}\right)$. Non-HGUs were not different in Sal-Ins and Fluv-Ins, respectively, during $P 1\left(11.1 \pm 2.9\right.$ and $\left.13.5 \pm 2.5 \mu \mathrm{mol} \cdot \mathrm{kg}^{-1} \cdot \mathrm{min}^{-1}\right)$ or $P 2$ $\left(12.2 \pm 2.2\right.$ vs. $\left.11.8 \pm 1.1 \mu \mathrm{mol} \cdot \mathrm{kg}^{-1} \cdot \mathrm{min}^{-1}\right)$. Endogenous glucose rate of appearance $\left(\mathrm{R}_{\mathrm{a}}\right)$ was suppressed by hyperglycemia in both groups to $\sim 35 \%$ of basal levels and did not differ between groups at any time. Glucose $\mathrm{R}_{\mathrm{d}}$ increased in response to hyperglycemia during $P 1$ and then stabilized (Table 2; NS between groups).

In Sal-INS and Fluv-INS, GIRs averaged $38.9 \pm 4.3$ and $30.9 \pm 2.1 \mu \mathrm{mol} \cdot \mathrm{kg}^{-1} \cdot \mathrm{min}^{-1}$, respectively, during Pl (NS), and they continued to increase during $P 2$, reaching $60.6 \pm 7.7$ and $49.5 \pm 6.8 \mu \mathrm{mol} \cdot \mathrm{kg}^{-1} \cdot \mathrm{min}^{-1}$ by $240 \mathrm{~min}(P=0.12$ between groups; Fig. 4). Non-HGU was significantly greater in Sal-INS than in Fluv-INS during $P l(27.5 \pm 3.8$ and $16.7 \pm$
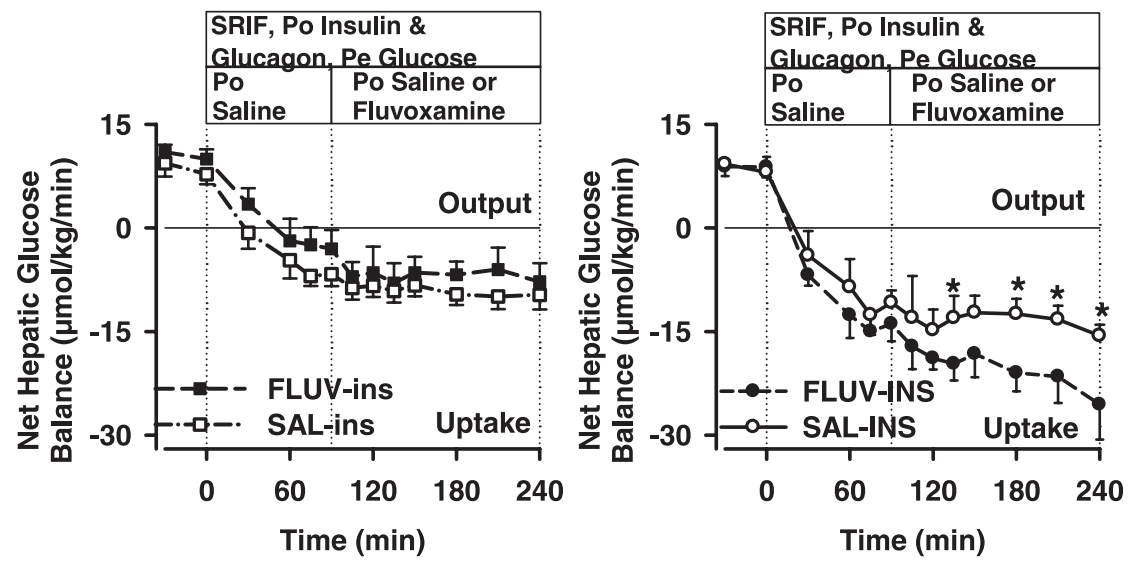

Fig. 3. Net hepatic glucose balance. See legend to Fig. 2 for description of study conditions. Data for Fluv-Ins and Sal-Ins are at left, with data for Sal-INS and Fluv-INS at right. There were no significant differences between Sal-ins and Fluv-ins. $* P<0.05$ between groups. 
$0.6 \mu \mathrm{mol} \cdot \mathrm{kg}^{-1} \cdot \mathrm{min}^{-1}$, respectively; $P<0.05$ ). It increased over time in both groups but appeared to be blunted in Fluv-INS (rates averaged $38.4 \pm 5.4$ and $20.0 \pm 1.3$ $\mu \mathrm{mol} \cdot \mathrm{kg}^{-1} \cdot \mathrm{min}^{-1}$ during $P 2, P<0.01$ between groups). Endogenous glucose $R_{a}$ was suppressed in the two groups to $\sim 15 \%$ of basal levels in response to hyperglycemia and hyperinsulinemia, and the rates did not differ between groups at any time. Glucose $R_{d}$ increased nearly fivefold between the basal period and the end of study in both groups. $\mathrm{R}_{\mathrm{d}}$ tended to be higher in Sal-INS during both $P 1$ and $P 2(P=0.4$ and 0.2 , respectively; Table 2).

Lactate metabolism, net hepatic carbon retention, and hepatic glycogen synthesis. The arterial blood lactate concentrations increased significantly during $P 1$ in all groups. The levels in Sal-Ins and Fluv-Ins did not differ at any time, nor did the concentrations in Sal-INS and Fluv-INS differ from each other (Table 3). All groups exhibited net hepatic lactate uptake in the basal period, shifting to net hepatic lactate output with the onset of the experimental period. The rates did not differ at any time in the two Ins groups or in the two INS groups.

Net hepatic carbon retention did not differ in Sal-Ins and Fluv-Ins groups at any time, but it was enhanced $(P<0.05)$ in Fluv-INS vs. Sal-INS during $P 2(18.5 \pm 2.7$ vs. $12.2 \pm 1.9$ $\mu \mathrm{mol} \cdot \mathrm{kg}^{-1} \cdot \mathrm{min}^{-1}$; Fig. 3). Net hepatic glycogen synthesis
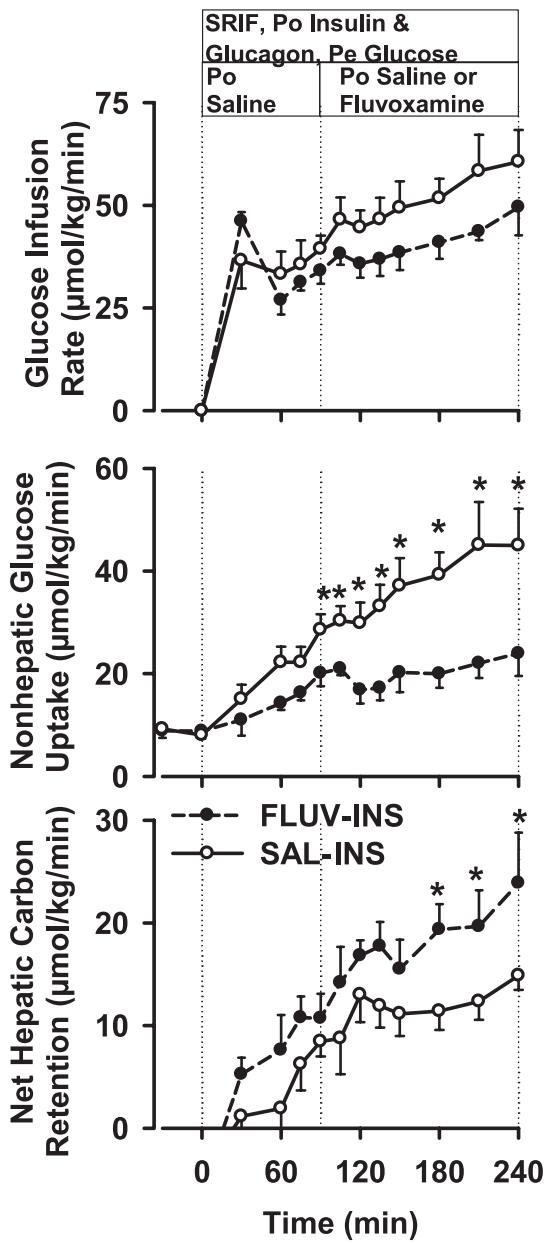

Fig. 4. Glucose infusion rate, nonhepatic glucose uptake, and net hepatic carbon retention in Fluv-INS and Sal-INS. See legend to Fig. 2 for description of study conditions. $* P<0.05$ between groups. over the 4-h experimental period, calculated from the hepatic glycogen concentrations, was greater in Fluv-INS than in Sal-INS (19.9 \pm 6.3 and $15.4 \pm 6.3 \mathrm{mg} / \mathrm{g}$ liver, respectively), although this did not reach statistical significance $(P=0.2)$.

Glycerol and NEFA metabolism. Arterial blood glycerol concentrations were reduced $\sim 15-40 \%$ by hyperglycemia and $50 \%$ by the combination of hyperglycemia and hyperinsulinemia, and net hepatic glycerol uptake was reduced $\sim 25-45 \%$ by hyperglycemia and $\sim 50 \%$ by hyperglycemia plus hyperinsulinemia (Table 3). Fluvoxamine had no effect on the degree of suppression in either the presence or absence of hyperinsulinemia. Arterial NEFA concentrations and net hepatic NEFA uptake changed in a manner similar to glycerol, and there were no differences between Sal-Ins and Fluv-Ins or between SalINS and Fluv-INS (Table 3).

\section{DISCUSSION}

Under conditions of basal insulin and hyperglycemia, intraportal fluvoxamine infusion had no significant impact on NHGU. The GIRs, glucose $R_{d}$, non-HGUs, and net hepatic carbon retention were similarly unaffected by fluvoxamine in the presence of basal insulin. However, in the presence of hyperinsulinemia, fluvoxamine was associated with rates of NHGU and net hepatic fractional extraction of glucose $>50 \%$ greater than in the saline-infused control animals $(P<0.05$ for both parameters). We were unable in our previous study to determine the time course of the response to fluvoxamine because that study employed three successive infusion rates of the SSRI (20). However, the current data indicate that the effect is relatively rapid, with a significant enhancement of NHGU evident within 45 min (Fig. 3).

The interaction between insulin and fluvoxamine also resulted in enhancement of hepatic glycogen storage, as evidenced by the significant enhancement of net hepatic carbon retention and the tendency toward greater net hepatic glycogen synthesis. Although the enhancement of net hepatic glycogen synthesis was similar in magnitude to the enhancement of net hepatic carbon retention in Fluv-INS vs. Sal-INS, it reflected glycogen accretion during both $P 1$ and $P 2$ rather than $P 2$ alone. The 150-min fluvoxamine infusion period was apparently not long enough to allow the SSRI to bring about a significant increase in the hepatic glycogen measurement.

There are several possible ways in which fluvoxamine (i.e., 5-HT) could enhance NHGU and hepatic glucose storage. First, it could act independently of insulin. Because that would imply that fluvoxamine could promote NHGU in the absence of insulin, and we failed to observe enhanced NHGU at basal insulinemia, this possibility seems unlikely. Second, fluvoxamine could enhance hepatic insulin sensitivity via a direct action. In this regard, more than one type of 5-HT receptor is known to be expressed in the liver $(10,16)$, providing a target through which fluvoxamine might act. Third, fluvoxamine might act indirectly on the liver by targeting nonhepatic tissues, bringing about an alteration in substrate supply from peripheral tissues or a change in neural or chemical signaling that in turn altered hepatic metabolism. Although we attempted to target the SSRI to the liver by choosing an agent with a high first-pass extraction and infusing it directly into the portal circulation, it is possible that sufficient fluvoxamine escaped the splanchnic bed to exert effects on remote sites. There were 
Table 3. Arterial lactate, glycerol, and NEFA concentrations and net hepatic balances

\begin{tabular}{|c|c|c|c|c|c|}
\hline \multirow{2}{*}{$\begin{array}{l}\text { Parameter } \\
\text { and Group }\end{array}$} & \multirow{2}{*}{$\begin{array}{l}\text { Basal } \\
\text { Period }\end{array}$} & \multirow{2}{*}{$\frac{P 1}{90 \mathrm{~min}}$} & \multicolumn{3}{|c|}{$P 2$} \\
\hline & & & $120 \mathrm{~min}$ & $180 \mathrm{~min}$ & $240 \mathrm{~min}$ \\
\hline \multicolumn{6}{|c|}{ Arterial blood lactate, $\mu \mathrm{mol} / \mathrm{l}$} \\
\hline Sal-Ins & $441 \pm 67$ & $933 \pm 112$ & $1,062 \pm 127$ & $1,166 \pm 161$ & $1,233 \pm 232$ \\
\hline Fluv-Ins & $669 \pm 107$ & $976 \pm 93$ & $1,069 \pm 60$ & $1,097 \pm 80$ & $1,184 \pm 92$ \\
\hline Sal-INS & $448 \pm 53$ & $922 \pm 100$ & $886 \pm 84$ & $898 \pm 82$ & $960 \pm 85$ \\
\hline Fluv-INS & $542 \pm 132$ & $1,093 \pm 126$ & $984 \pm 122$ & $982 \pm 133$ & $1,075 \pm 78$ \\
\hline \multicolumn{6}{|c|}{ Net hepatic lactate balance, $\mu \mathrm{mol} \cdot \mathrm{kg}^{-1} \cdot \mathrm{min}^{-1}$} \\
\hline Sal-Ins & $-7.3 \pm 0.9$ & $5.7 \pm 1.8$ & $5.0 \pm 1.2$ & $6.2 \pm 1.3$ & $4.8 \pm 2.2$ \\
\hline Fluv-Ins & $-9.7 \pm 2.1$ & $2.4 \pm 3.2$ & $1.8 \pm 2.6$ & $3.1 \pm 2.7$ & $4.6 \pm 2.4$ \\
\hline Sal-INS & $-7.7 \pm 1.5$ & $4.2 \pm 1.6$ & $3.2 \pm 1.5$ & $1.7 \pm 1.2$ & $1.2 \pm 0.7$ \\
\hline Fluv-INS & $-5.2 \pm 1.6$ & $6.1 \pm 0.5$ & $4.1 \pm 1.0$ & $3.4 \pm 1.2$ & $3.1 \pm 1.3$ \\
\hline \multicolumn{6}{|c|}{ Arterial blood glycerol, $\mu \mathrm{mol} / \mathrm{l}$} \\
\hline Sal-Ins & $86.1 \pm 6.2$ & $50.3 \pm 9.8$ & $44.8 \pm 6.4$ & $48.7 \pm 5.8$ & $52.1 \pm 9.9$ \\
\hline Fluv-Ins & $81.6 \pm 6.0$ & $69.4 \pm 13.3$ & $59.5 \pm 11.1$ & $46.1 \pm 5.8$ & $55.6 \pm 8.2$ \\
\hline Sal-INS & $89.4 \pm 10.9$ & $44.3 \pm 9.3$ & $39.8 \pm 8.2$ & $45.0 \pm 12.8$ & $40.0 \pm 10.4$ \\
\hline Fluv-INS & $81.2 \pm 4.2$ & $39.9 \pm 9.2$ & $39.2 \pm 13.0$ & $37.7 \pm 9.8$ & $37.1 \pm 8.7$ \\
\hline \multicolumn{6}{|c|}{ Net hepatic glycerol uptake, $\mu \mathrm{mol} \cdot \mathrm{kg}^{-1} \cdot \mathrm{min}^{-1}$} \\
\hline Sal-Ins & $1.9 \pm 0.2$ & $1.0 \pm 0.2$ & $0.8 \pm 0.1$ & $1.0 \pm 0.2$ & $0.9 \pm 0.2$ \\
\hline Fluv-Ins & $2.2 \pm 0.2$ & $1.6 \pm 0.2$ & $0.9 \pm 0.4$ & $1.2 \pm 0.2$ & $1.3 \pm 0.2$ \\
\hline Sal-INS & $1.8 \pm 0.4$ & $0.8 \pm 0.3$ & $0.6 \pm 0.2$ & $0.7 \pm 0.3$ & $0.7 \pm 0.3$ \\
\hline Fluv-INS & $2.1 \pm 0.3$ & $1.0 \pm 0.4$ & $1.1 \pm 0.7$ & $0.9 \pm 0.6$ & $1.0 \pm 0.5$ \\
\hline \multicolumn{6}{|c|}{ Arterial plasma NEFA, $\mu \mathrm{mol} / \mathrm{l}$} \\
\hline Sal-Ins & $916 \pm 46$ & $375 \pm 67$ & $353 \pm 58$ & $374 \pm 55$ & $379 \pm 61$ \\
\hline Fluv-Ins & $796 \pm 76$ & $555 \pm 128$ & $467 \pm 105$ & $401 \pm 67$ & $390 \pm 71$ \\
\hline Sal-INS & $820 \pm 174$ & $143 \pm 35$ & $138 \pm 38$ & $114 \pm 28$ & $118 \pm 30$ \\
\hline Fluv-INS & $1,020 \pm 133$ & $246 \pm 61$ & $212 \pm 55$ & $160 \pm 26$ & $178 \pm 35$ \\
\hline \multicolumn{6}{|c|}{ Net hepatic NEFA uptake, $\mu \mathrm{mol} \cdot \mathrm{kg}^{-1} \cdot \mathrm{min}^{-1}$} \\
\hline Sal-Ins & $2.9 \pm 0.2$ & $1.0 \pm 0.2$ & $1.0 \pm 0.2$ & $1.3 \pm 0.2$ & $0.8 \pm 0.2$ \\
\hline Fluv-Ins & $3.0 \pm 0.5$ & $2.0 \pm 0.7$ & $1.5 \pm 0.5$ & $1.4 \pm 0.3$ & $1.5 \pm 0.3$ \\
\hline Sal-INS & $2.9 \pm 0.6$ & $0.1 \pm 0.3$ & $0.1 \pm 0.2$ & $0.1 \pm 0.3$ & $0.1 \pm 0.2$ \\
\hline Fluv-INS & $3.1 \pm 0.3$ & $0.7 \pm 0.3$ & $0.5 \pm 0.2$ & $0.8 \pm 0.3$ & $0.7 \pm 0.3$ \\
\hline
\end{tabular}

Values are means \pm SE; $n=9,7,8$, and 6 for Sal-Ins, Fluv-Ins, Sal-INS, and Fluv-INS, respectively, except for nonesterified fatty acid (NEFA) concentrations and net hepatic uptake, where $n=5$ for Sal-INS. For group descriptions, see legend to Table 1. Negative values indicate net hepatic uptake. There were no significant differences between Ins groups or between INS groups.

no observable differences in lipolysis, as evidenced by circulating concentrations of glycerol and NEFA, and no differences in net uptake of these substrates by the liver, indicating that fluvoxamine is unlikely to have acted via a change in their supply to the liver. Escape of sufficient fluvoxamine to exert effects on the brain remains a possibility that deserves further study. Nevertheless, the results from our previous work with the intraportal infusion of 5-HT (22) could not have been dependent on brain effects, because 5-HT does not cross the blood-brain barrier (26). Finally, there may be an indirect insulin-sensitizing effect of 5-HT at the liver. For example, much of the effect of 5-HT on muscle glucose uptake appears to be due to its ability to alter blood flow $(3,31)$. Intraportal 5-HT infusion stimulated hepatic artery flow (22), but in the current studies there was no evidence for a fluvoxamineinduced alteration in hepatic blood flow in either the presence or absence of hyperinsulinemia. Thus it appears most likely that some chemical or neural signal induced by $5-\mathrm{HT}$ enhanced hepatic insulin sensitivity.

With regard to the last possibility, intraperitoneal injection of 5-hydroxytryptophan (5-HTP), the immediate precursor of 5 -HT, brought about hyperleptinemia in normal mice but not in those previously treated with streptozotocin to create insulin deficiency $(39,40)$. Moreover, subcutaneous insulin (1 U/kg) significantly enhanced the leptin response of normal mice given an intraperitoneal 5-HTP injection (38). Both the insulin and the leptin responses could be blocked by pretreatment with an intraperitoneal injection of benserazide, which prevents the formation of 5-HT from 5-HTP $(40,41)$. Leptin receptors are expressed in the liver $(13,15,28)$, and 2 days of intraperitoneal leptin administration increased hepatic insulin sensitivity and insulin receptor activation in vivo in mice (15). Thus stimulation of leptin release in response to fluvoxamine is a possible mechanism explaining our findings, but we cannot reach any conclusion about this from our current work.

Interestingly, glucagon concentrations did not decline during the experimental period in the groups receiving fluvoxamine (Table 1). We have consistently observed that plasma glucagon concentrations decline $\sim 15 \%$ during an infusion of a few hours duration (see, for example, Refs. 12, 20, 33), presumably because of the tendency of molecules of the hormone to aggregate in the infusate and become less available (18). We did not observe this in our previous dose-ranging study of fluvoxamine infusion (20), but in that study we infused fluvoxamine at the rate used in the current study for only $1 \mathrm{~h}$. It may be that the failure of glucagon concentrations to fall is 
seen only with longer infusions achieving higher levels of 5-HT, since it did appear to be present during intraportal infusion of 5-HT over $3 \mathrm{~h}$ (22). It is unlikely that fluvoxamine/ 5-HT stimulates glucagon secretion, both because we used somatostatin at a rate that has proven to control pancreatic endocrine secretion under a variety of stimulatory conditions (e.g., Refs. 7, 21) and because most data indicate that 5-HT and 5-HT receptor agonists have no effect (36) or an inhibitory effect $(1,4,17)$ on glucagon release in normal humans or animals. Thus it appears that fluvoxamine or endogenous 5-HT might slow the clearance of glucagon. Nevertheless, the failure of glucagon concentrations to decline in Fluv-INS in parallel with the levels in Sal-INS could not have been responsible for the enhancement of NHGU in the Fluv-INS group. If anything, a relative elevation of glucagon should reduce NHGU (9).

Non-HGU (primarily skeletal muscle glucose uptake under hyperinsulinemic conditions; Ref. 6) was significantly reduced during $P 2$ in Fluv-INS vs. Sal-INS, but it also tended to be lower in the Fluv-INS group during $P 1$. The GIR and glucose $\mathrm{R}_{\mathrm{d}}$ also tended to be lower in Fluv-INS than in Sal-INS throughout $P 1$ and $P 2$. The reduction in non-HGU and the tendency toward reduction in the GIR and glucose $\mathrm{R}_{\mathrm{d}}$ in $P 2$ may have been related directly or indirectly to administration of fluvoxamine (20). We have previously shown that there is substantial reciprocity between NHGU and non-HGU such that, under a variety of circumstances, when NHGU increases there is a compensatory decrease in non-HGU (e.g., Refs. 2, 6, $20,23)$. The current data are consistent in this respect with our previous findings. However, because of the tendency of nonhepatic and whole body glucose metabolism (i.e., non-HGU, GIR, glucose $\mathrm{R}_{\mathrm{d}}$ ) to differ during $P 1$, we cannot rule out a slight preexisting peripheral insulin resistance in Fluv-INS relative to the Sal-INS group. There is no evidence that the possible insulin resistance affected the liver, however, and therefore it had minimal impact on our findings.

In conclusion, intraportal infusion of fluvoxamine enhanced NHGU under hyperglycemic hyperinsulinemic conditions but not under euinsulinemic conditions. Enhancement of NHGU was accompanied by stimulation of net hepatic carbon retention and also by a tendency toward an offsetting decrease in non-HGU. Thus total body glucose $\mathrm{R}_{\mathrm{d}}$ was not significantly different in saline- and fluvoxamine-infused dogs. The apparent interaction between insulin and fluvoxamine suggests that SSRIs or related compounds that could be targeted to the hepatocyte might have a role in reducing postprandial hyperglycemia in individuals with impaired glucose tolerance or type 2 diabetes.

\section{ACKNOWLEDGMENTS}

We thank Jon Hastings and the members of the Vanderbilt Diabetes Research and Training Center Hormone Core Lab (Wanda Snead, Angelina Penaloza, and Eric Allen) for technical support.

\section{GRANTS}

This work was supported by a Research Award from the American Diabetes Association to M. C. Moore (National Institute of Diabetes and Digestive and Kidney Diseases Grant R01-DK-43706) and by Diabetes Research and Training Center Grant SP-60-AM-20593. The serotonin analyses were performed by the Center for Molecular Neuroscience Neurochemistry Core, supported in part by National Institute of Child Health and Human Development Grant P30HD-15022, managed by Raymond Johnson.

\section{REFERENCES}

1. Adeghate E, Ponery AS, Pallot D, Parvez SH, and Singh J. Distribution of serotonin and its effect on insulin and glucagon secretion in normal and diabetic pancreatic tissues in rat. Neuroendocrinol Lett 20: 315-322, 1999.

2. Adkins BA, Myers SR, Hendrick GK, Stevenson RW, Williams PE, and Cherrington AD. Importance of the route of intravenous glucose delivery to hepatic glucose balance in the conscious dog. J Clin Invest 79: 557-565, 1987.

3. Clerk LH, Smith ME, Rattigan S, and Clark MG. Nonnutritive flow impairs uptake of fatty acid by white muscles of the perfused rat hindlimb. Am J Physiol Endocrinol Metab 284: E611-E617, 2003.

4. Coulie B, Tack J, Bouillon R, Peeters T, and Janssens J. 5-Hydroxytryptamine-1 receptor activation inhibits endocrine pancreatic secretion in humans. Am J Physiol Endocrinol Metab 274: E317-E320, 1998.

5. Cowan JS and Hetenyi G Jr. Glucoregulatory responses in normal and diabetic dogs recorded by a new tracer method. Metabolism 20: 360-372, 1971.

6. Galassetti P, Shiota M, Zinker BA, Wasserman DH, and Cherrington AD. A negative arterial-portal vein glucose gradient decreases skeletal muscle glucose uptake in the conscious dog. Am J Physiol Endocrinol Metab 275: E101-E111, 1998.

7. Gustavson SM, Chu CA, Nishizawa M, Farmer B, Neal D, Yang Y, Donahue EP, Flakoll P, and Cherrington AD. Interaction of glucagon and epinephrine in the control of hepatic glucose production in the conscious dog. Am J Physiol Endocrinol Metab 284: E695-E707, 2003.

8. Hendrick GK, Frizzell RT, Williams PE, and Cherrington AD. Effect of hyperglucagonemia on hepatic glycogenolysis and gluconeogenesis after a prolonged fast. Am J Physiol Endocrinol Metab 258: E841-E849, 1990.

9. Holste LC, Connolly CC, Moore MC, Neal DW, and Cherrington AD. Physiological changes in circulating glucagon alter hepatic glucose disposition during portal glucose delivery. Am J Physiol Endocrinol Metab 273: E488-E496, 1997.

10. Hoyer D, Hannon JP, and Martin GR. Molecular, pharmacological and functional diversity of 5-HT receptors. Pharmacol Biochem Behav 71: 533-554, 2002.

11. Hsieh PS, Moore MC, Neal DW, Emshwiller M, and Cherrington AD. Rapid reversal of the effects of the portal signal under hyperinsulinemic conditions in the conscious dog. Am J Physiol Endocrinol Metab 276: E930-E937, 1999.

12. Hsieh PS, Moore MC, Neal DW, Venson P, and Cherrington AD. Hepatic glucose uptake rapidly decreases after elimination of the portal signal in conscious dogs. Am J Physiol Endocrinol Metab 275: E987E992, 1998.

13. Ikejima K, Lang T, Zhang YJ, Yamashina S, Honda H, Yoshikawa M, Hirose M, Enomoto N, Kitamura T, Takei Y, and Sato N. Expression of leptin receptors in hepatic sinusoidal cells. Comp Hepatol 3, Suppl 1: S12, 2004.

14. Keppler D and Decker K. Glycogen: determination with amyloglucosidase. In: Methods in Enzymatic Analysis, edited by Bergmeyer HU. New York: Verlag Chemie Weinheim-Academic, 1974, p. 1127-1131.

15. Lam NT, Lewis JT, Cheung AT, Luk CT, Tse J, Wang J, Bryer-Ash M, Kolls JK, and Kieffer TJ. Leptin increases hepatic insulin sensitivity and protein tyrosine phosphatase 1B expression. Mol Endocrinol 18: 1333-1345, 2004.

16. Li T, Leng XS, Weng SG, Peng JR, Wei YH, Mou DC, Wang WX, and Zhu JY. Expression of 5-hydroxytamine receptors in hepatic stellate cell and action of 5-hydroxytamine on biological characteristics of hepatic stellate cell. Zhonghua Wai Ke Za Zhi 41: 175-179, 2003.

17. Marco J, Hedo JA, Martinell J, Calle C, and Villanueva ML. Potentiation of glucagon secretion by serotonin antagonists in man. J Clin Endocrinol Metab 42: 215-221, 1976.

18. McGuinness OP, Fugiwara T, Murrell S, Bracy D, Neal D, O'Connor D, and Cherrington AD. Impact of chronic stress hormone infusion on hepatic carbohydrate metabolism in the conscious dog. Am J Physiol Endocrinol Metab 265: E314-E322, 1993.

19. Moore MC, Cherrington AD, Cline G, Pagliassotti MJ, Jones EM, Neal DW, Badet C, and Shulman GI. Sources of carbon for hepatic glycogen synthesis in the conscious dog. J Clin Invest 88: 578-587, 1991.

20. Moore MC, DiCostanzo CA, Dardevet D, Lautz M, Farmer B, Neal DW, and Cherrington AD. Portal infusion of a selective serotonin reuptake inhibitor enhances hepatic glucose disposal in conscious dogs. Am J Physiol Endocrinol Metab 287: E1057-E1063, 2004. 
21. Moore MC, Flakoll PJ, Hsieh PS, Pagliassotti MJ, Neal DW, Monohan MT, Venable C, and Cherrington AD. Hepatic glucose disposition during concomitant portal glucose and amino acid infusions in the dog. Am J Physiol Endocrinol Metab 274: E893-E902, 1998.

22. Moore MC, Geho WB, Lautz M, Farmer B, Neal DW, and Cherrington AD. Portal serotonin infusion and glucose disposal in conscious dogs. Diabetes 53: 14-20, 2004.

23. Moore MC, Hsieh PS, Neal DW, and Cherrington AD. Nonhepatic response to portal glucose delivery in conscious dogs. Am J Physiol Endocrinol Metab 279: E1271-E1277, 2000.

24. Moore MC, Pagliassotti MJ, Wasserman DH, Goldstein R, Asher J, Neal DW, and Cherrington AD. Hepatic denervation alters the transition from the fed to the food-deprived state in conscious dogs. J Nutr 123: 1739-1746, 1993

25. Myers SR, Biggers DW, Neal DW, and Cherrington AD. Intraportal glucose delivery enhances the effects of hepatic glucose load on net hepatic glucose uptake in vivo. J Clin Invest 88: 158-167, 1991.

26. Nathan $\mathbf{C}$ and Rolland $\mathbf{Y}$. Pharmacological treatments that affect CNS activity: serotonin. Ann NY Acad Sci 499: 277-296, 1987.

27. Nishizawa M, Moore MC, Shiota M, Gustavson SM, Snead WL, Neal DW, and Cherrington AD. Effect of intraportal glucagon-like peptide-1 on glucose metabolism in conscious dogs. Am J Physiol Endocrinol Metab 284: E1027-E1036, 2003.

28. Otte C, Otte JM, Strodthoff D, Bornstein SR, Folsch UR, Monig H, and Kloehn S. Expression of leptin and leptin receptor during the development of liver fibrosis and cirrhosis. Exp Clin Endocrinol Diabetes 112: 10-17, 2004

29. Pagliassotti MJ, Holste LC, Moore MC, Neal DW, and Cherrington AD. Comparison of the time courses of insulin and the portal signal on hepatic glucose and glycogen metabolism in the dog. J Clin Invest 97: 81-91, 1996.

30. Pussard E, Guigueno N, Adam O, and Giudicelli JF. Validation of HPLC-amperometric detection to measure serotonin in plasma, platelets, whole blood, and urine. Clin Chem 42: 1086-1091, 1996.
31. Rattigan S, Dora KA, Colquhoun EQ, and Clark MG. Serotoninmediated acute insulin resistance in the perfused rat hindlimb but not in incubated muscle: a role for the vascular system. Life Sci 53: 1545-1555, 1993.

32. Rothman DL, Magnusson I, Katz LD, Shulman RG, and Shulman GI. Quantitation of hepatic glycogenolysis and gluconeogenesis in fasting humans with 13C NMR. Science 254: 573-576, 1991.

33. Satake S, Moore MC, Igawa K, Converse M, Farmer B, Neal DW, and Cherrington AD. Direct and indirect effects of insulin on glucose uptake and storage by the liver. Diabetes 51: 1663-1671, 2002

34. Steele R, Wall JS, DeBodo RC, and Altszuler N. Measurement of size and turnover rate of body glucose pool by the isotope dilution method. Am J Physiol 187: 15-24, 1956.

35. Tatsumi M, Groshan K, Blakely RD, and Richelson E. Pharmacological profile of antidepressants and related compounds at human monoamine transporters. Eur J Pharmacol 340: 249-258, 1997.

36. Uvnas-Moberg K, Ahlenius S, Alster P, and Hillegaart V. Effects of selective serotonin and dopamine agonists on plasma levels of glucose, insulin and glucagon in the rat. Neuroendocrinology 63: 269-274, 1996.

37. Van Harten J. Overview of the pharmacokinetics of fluvoxamine. Clin Pharmacokinet 29: 1-9, 1995.

38. Yamada J, Sugimoto Y, and Ujikawa M. Effects of insulin and adrenalectomy on elevation of serum leptin levels induced by 5-hydroxytryptophan in mice. Biol Pharm Bull 26: 1491-1493, 2003.

39. Yamada J, Sugimoto Y, and Ujikawa M. The serotonin precursor 5-hydroxytryptophan elevates serum leptin levels in mice. Eur J Pharmacol 383: 49-51, 1999.

40. Yamada J, Sugimoto Y, Ujikawa M, Goko H, and Yagura T. Hyperleptinemia elicited by the 5-HT precursor, 5-hydroxytryptophan in mice: involvement of insulin. Life Sci 73: 2335-2344, 2003.

41. Yamada J, Ujikawa M, and Sugimoto Y. Serum leptin levels after central and systemic injection of a serotonin precursor, 5-hydroxytryptophan, in mice. Eur J Pharmacol 406: 159-162, 2000.

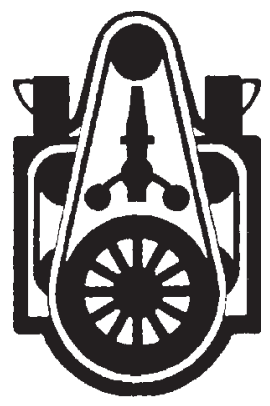

